\begin{tabular}{|c|c|c|c|}
\hline $\begin{array}{l}\square \text { Artikel Pengabdian } \\
\text { च Info Artikel : } \\
\text { Diterima : } 29 \text { Des } 2021 \\
\text { Dipublikasi : } 20 \text { Jan } 2022\end{array}$ & \begin{tabular}{|c|c|}
$\begin{array}{c}\text { OPEN } \\
\text { ACCES }\end{array}$ & (\%) \\
Goggle \\
\end{tabular} & $\begin{array}{r}e-I S S N \text { : 2685-677X } \\
\text { http://www.jurnal.ummu.ac.id/index.php/BIOSAINSTEK } \\
\text { Jurnal BIOSAINSTEK. Vol. 4 No. 1, 62-65 } \\
\text { DoI: https://doi.org/10.52046/biosainstek.v4i1.62-65 }\end{array}$ & Quige \\
\hline
\end{tabular}

\title{
Perubahan Perilaku Hidup Sehat, Masyarakat Bebas Karies Gigi di Negeri Lesluru, Kecamatan Teon Nila Sarua Maluku Tengah
}

\author{
Lydia M.Ivakdalam ${ }^{1 凶}$ \\ 1 Staf Pengajar Staf Pengajar Fakultas Kesehatan Universitas Kristen Indonesia Maluku, Ambon, Indonesia. \\ Email : ivakdlmlydia@gmail.com \\ ${ }^{凶}$ Korespondensi : Lydia M.Ivakdalam, Universitas Kristen Indonesia Maluku. Ambon, Indonesia,
Email : ivakdlmlydia@gmail.com
}

\begin{abstract}
ABSTRAK
Kebersihan mulut dan gigi mempunyai arti yang penting karena, apabila tidak dibersihkan secara sempurna maka sisa makanan yang terselip bersama bakteri akan melekat pada gigi dan dapat memproduksi asam. Organ tubuh gigi perlu dijaga dengan baik mengingat fungsinya sebagai alat untuk mengunyah makanan, berbicara dan tampilan kecantikan. Gangguan kesakitan dapat menghambat aktifitas dan kenyamanan dalam bekerja dan atau belajar. Lokasi sosialisasi kebersihan mulut dan gigi di SD Inpres Lesluru. Permasalahan yang ditemui adalah adanya karies gigi dan kerusakan pada gigi, hal ini diakibatkan ketidaktahuan anak-anak tentang cara menggosok gigi yang benar. Solusi yang ditawarkan adalah memberikan sosialisasi tentang kesehatan gigi dan mulut. Hasil kegiatan menunjukkan bahwa 90\% siswa senang makan jajanan yang manis-manis, $20 \%$ siswa sudah melakukan kegiatan menggosok gigi dua kali sehari (pagi sebelum kesekolah dan malam sebelum tidur), 40\% siswa menggosok gigi hanya di pagi hari sebelum berangkat ke sekolah dan sisanya belum rutin menggosok gigi, $35 \%$ siswa sudah paham cara menggosok gigi dengan benar, $100 \%$ siswa sudah menggosok gigi mengunakan pasta gigi, rata-rata siswa pernah mengalami sakit gigi antara 3-4 kali per tahun, dan $90 \%$ siswa sudah bisa melakukan proses menggosok gigi secara baik dan benar.
\end{abstract}

Keyword: karies gigi, kebersihan, gigi, mulut

\section{PENDAHULUAN}

\subsection{Latar Belakang}

Kesehatan masyarakat merupakan hal penting bagi suatu negara karena, negara akan dikatakan aman dan sejahtera ketika taraf kesehatan mayarakat terjamin. Kesehatan masyarakat dapat terjamin ketika memahami pentingnya olah raga dan istirahat yang cukup, dan konsumsi makanan bergizi yang sangat diperlukan tubuh. Mengkonsumsi makanan bergizi sangat baik bagi tubuh dalam memperoleh pertumbuhan yang sehat.

Konsumsi makanan bergizi mengandung karbohidrat, lemak, protein, vitamin, mineral dan air. Namun tidak jarang dengan adanya kemajuan teknologi dan kesibukan orang tua dalam bekerja, menyebabkan masyarakat lebih cenderung memilih makanan siap saji yang tersedia dipasaran. Mengkonsumsi makanan siap saji yang cenderung memiliki tingkat gizi yang tidak seimbang, dan kebersihan makanan yang tidak terjamin dapat berdampak buruk bagi kesehatan.

Konsumsi makanan dengan kandungan gizi tidak seimbang dapat berdampak pada kesehatan mulut dan gigi. Untuk itu kesehatan mulut dan gigi perlu diperhatikan sedini mungkin karena, sifat makanan dapat meningatkan kejadian sakit pada gigi. Konsumsi makanan yang mengandung kariogenik atau makan yang banyak mengandung karbohidrat, makan yang lengket dan mudah hancur dalam mulut, dapat dengan mundah membentuk terjadinya kerusakan gigi.

Kebersihan mulut dan gigi mempunyai arti yang penting karena, apabila tidak dibersihkan secara sempurna maka sisa makanan yang terselip bersama bakteri akan melekat pada gigi dan dapat memproduksi asam. Produksi asam terbentuk terus menerus akan mengancurkan email gigi yang mengakibatkan terjadinya karies. Bukan hanya karies namun dapat menimbulkan radang gusi, kalkulus, dan halitosis, Penyebab utamanya disebabkan oleh kebersihan mulut dan pola makan yang kurang baik (Depkes RI.2009) 
Organ tubuh gigi perlu dijaga dengan baik mengingat fungsinya sebagai alat untuk mengunyah makanan, berbicara dan tampilan kecantikan (Pratiwi, 2007). Salah satu organ tubuh terkecil sekalipun ketika mengalami gangguan, akan menyebabkan kesakitan bagi orang yang mengalaminya. Kesakitan tersebut dapat menghambat aktifitas dan kenyamanan keseluruhan tubuh (Triyanto, 2017). Untuk itu pentingnya memahami kesehatan gigi secara dini sangat diperlukan dalam pendidikan kesehatan. Pemahaman kesehatan gigi dan mulut perlu diketahui dan pahami oleh orang tua dan anak-anak.

Pendidikan kesehatan tidak semata suatu kegiatan pelajaran di kelas, tetapi merupakan kumpulan pengalaman dari, kapan dan dimana saja sepanjang dapat mempengaruhi pengetahuan sikap dan kebiasaan baik. Pendidikan kesehatan tidak dapat secara mudah diberikan oleh seseorang kepada orang lain, karena pada akhirnya sasaran pendidikan itu sendiri harus dapat mengubah kebiasaan dan tingkah laku perseorangan. Menurut Gede dalam Prasko (2016) Pengetahuan yang kurang mengenai kebersihan gigi dan mulut merupakan salah satu penyebab anak mengabaikan masalah kesehatan gigi dan mulut. Berdasarkan uraian tersebut, maka penting dilakukan pendidikan kesehatan tentang kebersihan gigi dan mulut melalui kegiatan sosialisasi.

\subsection{Permasalahan Mitra}

Kegiatan KKN-PPM Angkatan LIII berlokasi di Negeri Lesluru Kecamatan Teon Nila Serua (TNS), Kabupaten Maluku Tengah. Survei awal terkait kebersihan gigi dan mulut ditujukan bagi anak usia sekolah kelas 1 sampai 3 di Negeri Lesluru. Hasil survei menunjukkan adanya masalah timbulnya karies gigi dan kerusakan pada gigi, hal ini diakibatkan ketidaktahuan anak-anak tentang cara menggosok gigi yang benar.

\subsection{Solusi Permasalahan}

Berdasarkan permasalahan tersebut, maka solusi yang ditawarkan adalah memberikan sosialisasi tentang kesehatan gigi dan mulut. Kegiatan sosialisasi dimaksudkan untuk meningkatkan pemahaman dan adanya perubahan sikap peserta sosialisasi. Berperilaku hidup bersih dan sehat akan meningkatkan kualitas dan produktifitas hidup serta ketahanan diri dari serangan berbagai penyakit. Sasaran sosialisasi adalah anak-anak yang bersekolah di SD Inpres Lesluru, karena menurut Middle Cook dalam Answar (2009), pengulangan pesan dapat membantu perubahan sikap sehingga tidak sampai menimbulkan kesakitan yang lebih beresiko.

\section{METODE PELAKSANAAN}

Metode yang digunakan dalam kegiatan pengabdian kepada masyarakat meliputi beberapa tahapan antara lain;

1. Analisa /Observasi situasi Masyarakat Negeri Lesluru.

Pertama melakukan kunjungan dan komunikasi dengan perangkat desa, masyarakat, organisasi pemuda, ibu-ibu PKK, Guru, tenaga Kesehatan desa dan organisasi keagamaan. Proses pengenalan dan mengetahui kebutuhan masyarakat lebih rinci, sehingga kegiatan pengabdian masyarakat berlangsung tepat sasaran.

2. Identifikasi Masalah

Berdasarkan hasil analisa maka dilakukan identifikasi masalah di bidang kesehatan diakibatkan ketidaktahuan anak-anak tentang cara menggosok gigi yang benar sehingga, dilakukan program sosialisasi kebersihan gigi dan mulut bagi siswa kelas 1, 2, dan 3.

\section{HASIL DAN LUARAN YANG DICAPAI}

Sebelum kegiatan dilakukan, Tim KKN-PPM melakukan koordinasi bersama Kepala Sekolah terkait proses sosialisasi (Gambar 1 dan 2). Kegiatan sosialisasi kebersihan gigi dan mulut dilaksanakan pada tanggal 25 November 2021 bertempat di salah satu ruang kelas SD Inpres Lesluru, diikuti oleh siswa kelas 1 sampai 3 sebanyak 51 orang. Kegiatan dimulai dari pukul 08.00 dan selesai pada pukul 10.30 WIT.

Pendekatan sosialisasi yang digunakan oleh Tim KKN-PPM adalah permainan (games) sehingga menarik minat siswa mengikuti kegiatan sosialisasi dan berinteraksi dalam kegiatan. Siswa kelas 1 sampai 3 digabung, lalu dikelompokkan menjadi 3 kelompok. Setiap kelompok akan berlomba menjawab beberapa pertanyaan tentang tentang perawatan organ tubuh bagian mulut dan gigi, hal ini dimaksudkan untuk mengetahui tingkat pemahaman siswa tentang perawatan kebersihan gigi dan mulut. Beberapa pertanyaan permainan yang disampaikan antara lain: apa makanan kesukaan, berapa kali menggosok gigi dalam 1 hari, kapan melakukan gosok gigi, bagaimana cara menggosok gigi, 
apakah mengunakan pasta gigi. Selanjutnya siswa juga diberikan coklat dan sikat gigi, lalu siswa diminta memberikan pendapat terkait hal ini. Pertanyaan perorangan lainnya yaitu berapa kali pernah merasakan sakit gigi dan kapan terakhir kali memeriksa gigi di puskesmas.

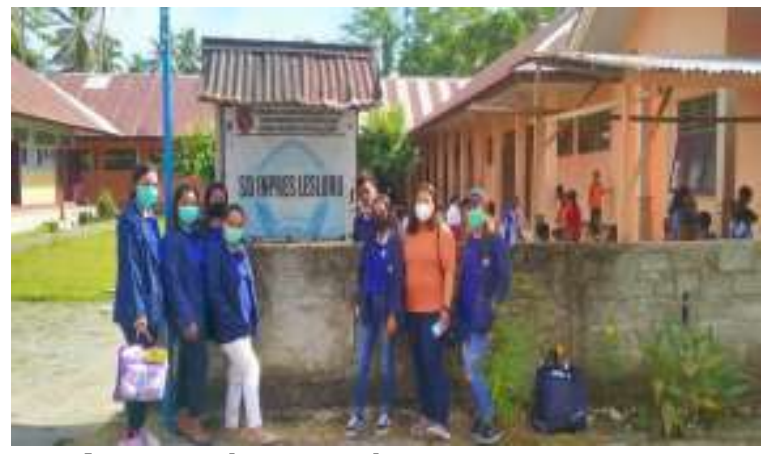

Gambar 1. Lokasi Sosialisasi

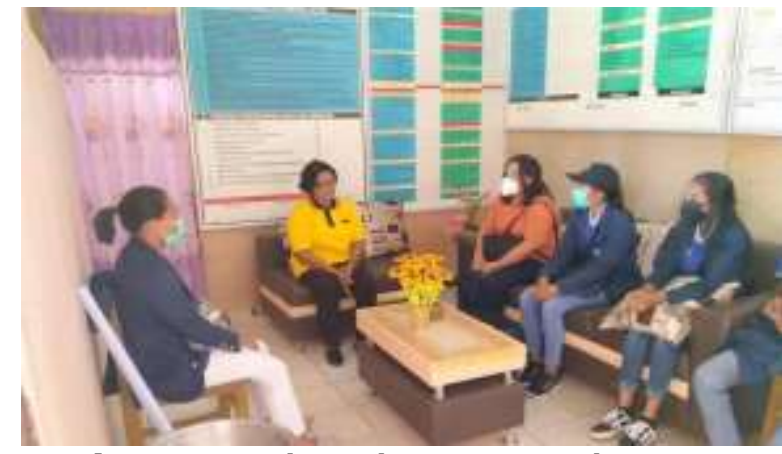

Gambar 2. Koordinasi bersama Kepala SD Inpres Lesluru

Hasil permainan menunjukkan bahwa 90\% siswa senang makan jajanan yang manis-manis, 20\% siswa sudah melakukan kegiatan menggosok gigi dua kali sehari (pagi sebelum kesekolah dan malam sebelum tidur), sisanya 40\% siswa menggosok gigi hanya di pagi hari sebelum berangkat ke sekolah dan sisanya belum rutin menggosok gigi, 35\% siswa sudah paham cara menggosok gigi dengan benar, $100 \%$ siswa sudah menggosok gigi mengunakan pasta gigi, dan rata-rata siswa pernah mengalami sakit gigi antara 3-4 kali per tahun.

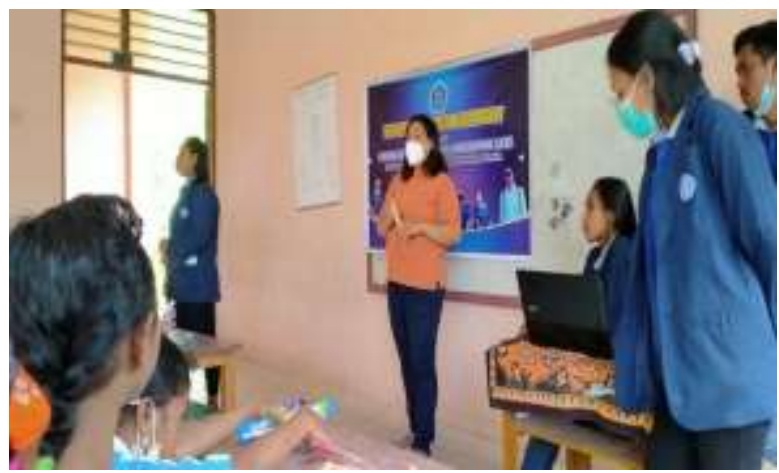

Gambar 3. Sosialisasi dalam Bentuk Permainan

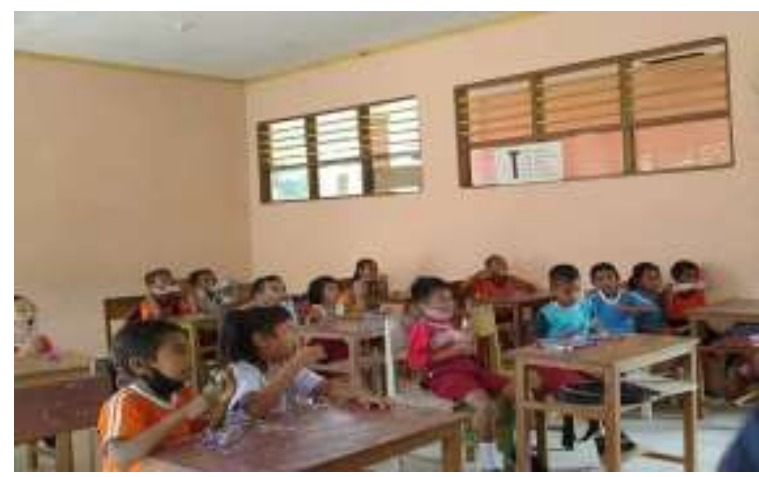

Gambar 4. Siswa Praktek Cara Menggosok Gigi yang Baik dan Benar

Usia sekolah dasar merupakan saat ideal untuk melatih kemampuan motoric seorang anak, termasuk menyikat gigi (Riyanti \& Saptarini, 2012). Setelah melakukan sosialisasi, siswa melakukan praktek cara menggosok gigi yang baik dan benar yang diawali dengan mengkonsumsi coklat yang dibagikan dan setelah itu melakukan gosok gigi bersama. Menunjang kegiatan tersebut setiap siswa dibagikan sikat gigi dan pasta gigi untuk dibawa pulang sebagai milik pribadi. Hasil praktek menunjukkan bahwa 90\% siswa sudah bisa menggosok gigi secara baik dan benar. Menurut Budisuari, (2010), anak yang menggosok gigi mempunyai kecenderungan terjadinya karies lebih ringan dibandingkan yang tidak mengosok gigi.

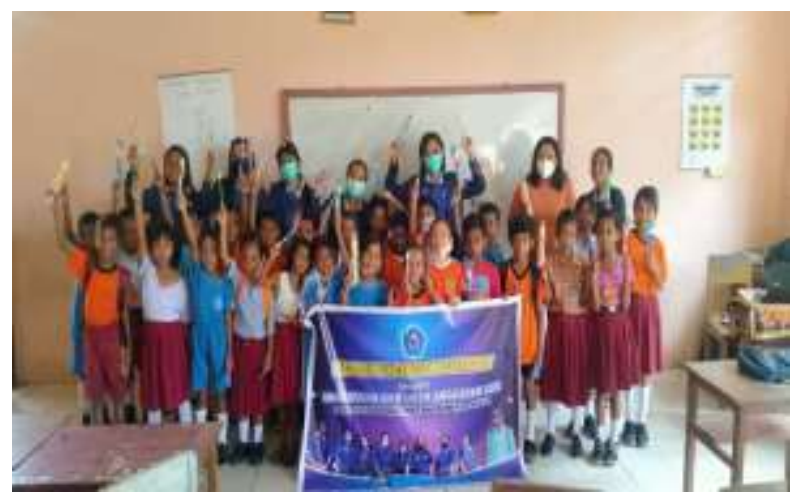

Gambar 5. Foto Bersama Tim KKN-PPM dan Peserta Sosialisasi 


\section{PENUTUP}

Kegiatan sosialisasi kebersihan gigi dan mulut dapat berlangsung secara baik, hal ini diindikasikan adanya respon aktif siswa dalam pelaksanaan sosialisasi, adanya respon timbal-balik dalam menjawab pertanyaan maupun bertanya, serta komitmen untuk tertib menggosok gigi secara mandiri dan berkelanjutan.

\section{UCAPAN TERIMA KASIH}

Pelaksanaan kegiatan pengabdian tidak terlepas dari bantuan berbagai pihak, baik bantuan finansial maupun non finansial. Untuk itu penulis menyampaikan ucapam terima kasih kepada Rektor Universitas Kristen Indonesia Maluku, Kepala Lembaga Pengabdian Masyarakat, Kepala Negeri Lesluru, Guru, siswa kelas 1 sampai 3, dan orang tua murid.

\section{DAFTAR PUSTAKA}

Azwar, S. 2009. Sikap Manusia, Teori dan Pengukuran. Yogyakarta: Pustaka Pelajar

Budisuari, M, A, dkk. 2010. Hubungan Pola Makan dan Kebiasaan Menyikat Gigi dengan Kesehatan Gigi dan Mulut (Karies) di Indonesia. Buletin Penelitian Sistem Kesehatan. Vol 13. No 1. http://isjd.pdii.lipi.go.id/admin/jurnal /131108391.pdf.

Depkes RI, Profil Kesehatan Indonesia 2000, http://www.depkes.go.id. 2009,

Pratiwi, D. 2007. Gigi Sehat. Jakarta: PT. Kompas Media Nusantara.

Prasko, Sutomo, B, Santoso, B, Penyuluhan Metode Audio Visual Dan Demonstrasi Terhadap Pengetahuan Menyikat Gigi Pada Anak Sekolah Dasar. Jurnal Kesehatan Gigi, Desember 2016; Vol.03 No.2

Riyadi, S, \& Sukarmin. 2009. Asuhan Keperawatan pada Anak. 